\title{
Penentuan Daerah Penyangga Kawasan Taman Hutan Raya Bukit Soeharto di Kecamatan Samboja, Kutai Kartanegara
}

\author{
Determination of the buffer zone for the Taman Hutan Raya Bukit Soeharto \\ in Samboja District, Kutai Kartanegara
}

\author{
Desy Ariyani $^{\mathrm{a}}$, Elin Diyah Syafitri ${ }^{\mathrm{b}}$, Rahmi Yorika $^{\mathrm{b} *}$ \\ ${ }^{a}$ Mahasiswa Perencanaan Wilayah dan Kota, Balikpapan, Indonesia \\ ${ }^{b}$ Dosen Perencanaan Wilayah dan Kota, Balikpapan, Indonesia
}

\begin{abstract}
Abstrak
Taman Hutan Raya (Tahura) Bukit Soeharto merupakan kawasan konservasi yang ditetapkan berdasarkan Keputusan Menteri Kehutanan 1231 tahun 2017 memiliki luas 64.814,98 Ha, dari total luasan terdapat pemanfatan lahan pertambangan dengan luas $956 \mathrm{Ha}$, perkebunan seluas $52 \mathrm{Ha}$, permukiman atau lahan terbangun seluas $173 \mathrm{Ha}$ dan petanian dengan luas $16.915 \mathrm{Ha}$. Dimana terdapat 21,29\% dari total luas Taman Hutan Raya Bukit Soeharto dan daerah penyangga yang dipergunakan untuk pertambangan, pertanian lahan kering campuran, pertanian lahan kering, tanah kosong /terbuka, pemukiman, tambak/perikanan dan perkebunan. Hal ini dikarenakan masyarakat tidak mengetahui batasan wilayah untuk memanfaatkan sumberdaya hutan sehingga terjadi pemanfataan lahan yang tidak seharusnya. Selain itu, masyarakat juga tidak mengetahui bahwa kawasan konservasi tidak boleh dimanfaatkan. Penelitian ini bertujuan untuk menentukan wilayah yang berfungsi sebagai daerah penyangga kawasan Taman Hutan Raya (Tahura) Bukit Soeharto. Penelitian menggunakan metode overlay peta dengan alat analisis Arcgis 10.7 dengan parameter penentuan fungsi kawasan adalah kemiringan lahan, jenis tanah dan curah hujan. Berdasarkan hasil analisis yang telah dilakukan diperoleh hasil bahwa terdapat wilayah dengan luas sebesar 2.2 Ha yang memiliki fungsi sebagai daerah penyangga. Wilayah tersebut termasuk dalam wilayah administrasi Kelurahan Sungai Merdeka, Wonotirto, dan Karya Jaya.
\end{abstract}

Kata kunci: Daerah Penyangga, Kawasan Konservasi, Pemanfaatan lahan

\begin{abstract}
The Taman Hutan Raya (Tahura) Bukit Soeharto is a conservation area established based on the Decree of the Minister of Forestry 1231 of 2017 with an area of 64,814.98 Ha, of the total area there are land uses such as mining with an area of $956 \mathrm{Ha}, 52 \mathrm{Ha}$ of plantations, settlements or land. built with an area of 173 hectares and a farm with an area of 16,915 hectares Where there are $21.29 \%$ of the total area of the Bukit Soeharto Grand Forest Park and its buffer areas which are used for mining, mixed dry land farming, dry land farming, empty / open land, settlements, ponds / fisheries and plantations. This is because the community does not know the boundaries of the area to utilize forest resources, resulting in improper use of land, this is because people do not know that conservation areas should not be used. The research aims to determine the area that functions as a buffer area for the Taman Hutan Raya (Tahura) Bukit Soeharto. The study used a map overlay method with Arcgis 10.7 analysis tool with parameters for determining the function of the area are land slope, soil type and rainfall. Based on the results of the analysis that has been done, it is found that there is an area of $2.2 \mathrm{Ha}$ which has a function as a buffer zone. This area is included in the administrative area of Sungai Merdeka, Wonotirto, and Karya Jaya Villages.
\end{abstract}

Keyword: Buffer areas, conservation areas, landuse.

\footnotetext{
* Corresponding author. Desy Ariyani.

E-mail address: ariyanidesy027@gmail.com.
} 


\section{Pendahuluan}

Peraturan Pemerintah Nomor 68 Tahun 1998 tentang Kawasan Suaka Alam dan Kawasan Pelestarian Alam menyatakan bahwa daerah penyangga memiliki fungsi untuk menjaga kawasan suaka alam dan pelestarian alam dari berbagai tekanan dan gangguan yang berasal dari luar ataupun dalam kawasan yang dapat mengakibatkan perubahan keutuhan atau fungsi kawasan. Selain itu, berdasarkan Peraturan Pemerintah Nomor 68 Tahun 1998 tentang Kawasan Suaka Alam dan Kawasan Pelestarian Alam menyebutkan bahwa penetapan daerah penyangga memiliki beberapa kriteria. Kriteria yang pertama adalah secara geologi berbatasan dengan kawasan suaka alam dan pelestarian alam, yang kedua adalah secara ekologis memiliki pengaruh yang baik dari luar ataupun dalam kawasan, dan yang ketiga adalah mampun menahan berbagai gangguan baik dari dalam ataupun luar kawasan (Peraturan Pemerintah Nomor 68 tahun 1998). Namun tidak semua kawasan konservasi telah ditetapkan daerah penyangganya Taman Hutan Raya (Tahura) Bukit Soeharto merupakan kawasan pelestarian alam yang ditetapkan berdasarkan Keputusan Menteri Kehutanan 1231 tahun 2017 memiliki luas 64.814,98 Ha. Akan tetapi pemerintah daerah belum mengatur peraturan terkait dengan batas-batasan daerah disekitar Taman Hutan Raya (Tahura) Bukit Soeharto yang menjadi daerah penyangga sehingga terdapat pemanfaatan yang tidak sesuai dengan fungsinya sebesar 21,29\% dari total luas Taman Hutan Raya Bukit Soeharto. Daerah penyangga Taman Hutan Raya Bukit Soeharto dipergunakan untuk pertambangan, pertanian lahan kering campuran, pertanian lahan kering, tanah kosong /terbuka, pemukiman, tambak/perikanan dan perkebunan (Suryadi, dkk, 2017). Terdapat sembilan kelurahan di Kecamatan Samboja yang berpotensi sebagai daerah penyangga dan memiliki wilayah administrasi yang berbatasan dengan wilayah Taman Hutan Raya Bukit Soeharto. Sembilan kelurahan tersebut yaitu Kelurahan Bukit Merdeka, Sei Merdeka, Sei Seluang, Margomulyo, Argosari, Ambarawang Laut, Karya Jaya, Wonotirto dan Tanjung Harapan. Kelurahan tersebut memiliki total jumlah warga sebesar 22.732 jiwa yang berpeluang memanfaatkan lahan guna memenuhi kebutuhannya baik untuk tempat tinggal atau mata pencaharian. Oleh karena itu, perlu adanya penentuan daerah penyangga agar masyarakat tidak salah dalam memanfaatkan sumber daya hutan. Selain itu, dengan adanya penentuan daerah penyangga secara jelas maka fungsi daerah penyangga dapat diwujudkan secara optimal dengan pengelolaan pemanfaatan jasa lingkungan, nilai ekonomi, dan konservasi lahan masyarakat, melalui rehabilitasi lahan kritis dalam sistem hutan kemasyarakatan, hutan rakyat atau agroforestri.

\section{Metode}

Metode analisis yang digunakan yaitu analisis fungsi kawasan, dalam proses analisis terdapat 3 (tiga) teknik analisis data yaitu skoring, overlay, dan desktiptif. Skoring yang dimaksud adalah pemberian nilai atau bobot mennggunakan parameter kelerengan, jenis tanah dan curah hujan untuk membuat fungsi kawasan yang sesuai yaitu pada tabel berikut.

Tabel 1. Parameter kelerengan (Peraturan Menteri Pekerjaan Umum Nomor 41 Tahun 2007)

\begin{tabular}{clllr}
\hline Kelas & & Kemiringan $(\%)$ & \multicolumn{1}{c}{ Klasifikasi } & Nilai skor \\
\hline 1 & $0-8$ & Datar & 20 \\
2 & $8-15$ & Landai & 60 \\
3 & $15-25$ & Agak curam & 80 \\
4 & $25-45$ & Curam & 100 \\
5 & $>45$ & Sangata curam &
\end{tabular}

Tabel 2. Parameter jenis tanah (Peraturan Menteri Pekerjaan Umum Nomor 41 Tahun 2007)

\begin{tabular}{cllr}
\hline Kelas & \multicolumn{1}{c}{ Jenis Tanah } & \multicolumn{1}{c}{ Klasifikasi } & Nilai skor \\
\hline 1 & Aluvial, Planosol, Hidromorf, Laterik air & Tidak peka & 15 \\
2 & tanah. & Katosol . & 30 \\
3 & Brown forest soil, Podsolic, Non calcic & Agak peka & 45 \\
4 & brown mediteran. & & \\
5 & Andosol, Laterit, Grumusol, Podsol. & Peka & 60 \\
& Regosol, Litosol, Organosol, Rensina & Sangata peka & 175
\end{tabular}


Tabel 3. Parameter curah hujan (Peraturan Menteri Pekerjaan Umum Nomor 41 Tahun 2007)

\begin{tabular}{cllr}
\hline Kelas & \multicolumn{1}{c}{ Intensistas Hujan $(\mathrm{mm} /$ hari $)$} & \multicolumn{1}{c}{ Klasifikasi } & Nilai skor \\
\hline 1 & $0-13,6$ & Sangat rendah & 10 \\
2 & $13,6-20,7$ & Rendah & 20 \\
3 & $20,7-27,7$ & Sedang & 30 \\
4 & $27,7-34,8$ & Tinggi & 40 \\
5 & $>34,8$ & Sangata tinggi & 50
\end{tabular}

Teknik yang digunakan dalam penenelitian adalah mengintegrasikan hasil pengolahan data penginderaan jauh dengan analisis sistem informasi geografis menggunakan teknik overlay atau tumpang susun beberapa parameter yaitu curah hujan, kemiringan lereng dan jenis tanah hasilnya akan berupa peta arahan fungsi kawasan. Formura pembuatan peta arahan fungsi kawasan.

$$
A F K=K L+J T+C H
$$

$$
\begin{aligned}
& \text { Keterangan: } \quad \text { AFK }=\text { Skor Total Arahan Fungsi Kawasan } \\
& \mathrm{KL}=\text { Skor Kemiringan Lereng } \\
& \text { JT }=\text { Skor Jenis tanah } \\
& \mathrm{CH}=\text { Skor Curah Hujan }
\end{aligned}
$$

Tabel 4. Kriteria penetapan kawasan lindung dan budidaya (Peraturan Menteri Pekerjaan Umum Nomor

\begin{tabular}{clr}
\multicolumn{2}{c}{41 Tahun 2007) } \\
\hline No. & \multicolumn{1}{c}{ Fungsi kawasan } & \multicolumn{1}{c}{ Total Nilai Skor } \\
\hline 1. & Kawasan Lindung & $\geq 175$ \\
2. & Kawasan Penyangga & $125-174$ \\
3. & Kawasan Budidaya Tanaman Tahunan & $<125$ \\
4. & Kawasan Tanaman Semusim dan Permukiman & $<125$ dan kelerengan $<8 \%$
\end{tabular}

\section{Kajian literatur}

\subsection{Fungsi Pemanfaatan Lahan}

Fungsi pemanfaatan lahan merupakan kajian terhadap potensi lahan untuk peruntukkan suatu kegiatan pada kawasan tertentu berdasarkana fungsi utamannya (Luntungan dalam listumbinang Halengkara, 2012). Fungsi kawasan terbagi menjadi empat yaitu kawasan lindung, kawasan penyangga, dan kawasan budidaya tanaman tahunan, dan kawasan budidaya tanaman semusim. Menurut Peraturan Menteri Negara Lingkungan Hidup Nomor 17 Tahun 2009 menyatakan bahwa kawasan lindung adalah wilayah yang ditetapkan dengan fungsi utama melindungi kelestarian lingkungan hidup yang mencakup sumber daya alam dan sumber daya buatan. Fungsi utama kawasan lindung adalah sebagai perlindungan sistem penyangga kehidupan untuk mengatur tata air, mencegah banjir, mengendalikan erosi, mencegah intrusi air laut dan memelihara kesuburan tanah. (Nugraha, dkk 2006). Kawasan penyangga adalah kawasan yang ditetapkan untuk menopang keberadaan kawasan lindung sehingga fungsi lindungnya tetap terjaga. (Nugraha, dkk 2006) dalam Muryono (2008). Kawasan penyangga adalah batas antara kawasan lindung dan kawasan budidaya. Kawasan budidaya adalah wilayah yang ditetapkan dengan fungsi utama untuk dibudidayakan atas dasar kondisi dan potensi sumber daya alam, sumber daya manusia, dan sumber daya buatan (PP RI No. 26 tahun 2008). Kawasan budidaya dibedakan menjadi kawasan budidaya tanaman tahunan dan kawasan budidaya tanaman semusim. Berdasarkan Peraturan Menteri Perkerjaan Umum Nomor 41 Tahun 2007 dalam menentukan fungsi kawasan menggunakan 3 (tiga) parameter untuk menentukan fungsi kawasan yaitu sebagai berikut :

\section{a. Kemiringan Lereng}

Kemiringan lereng adalah bentuk dari variasi perubahan permukaan bumi secara global, regional atau dikhususkan dalam bentuk suatu wilayah tertentu. Variabel yang digunakan dalam 
pengidentifikasian kemiringan lereng adalah sudut kemiringan lereng, titik ketinggian di atas permukaan laut dan bentang alam berupa bentukan akibat gaya satuan geomorfologi yang bekerja.

b. Jenis Tanah

Jenis tanah dibentuk pada lingkungan fisiografis dan proses yang sama. Faktor fisiografis seperti batuan induk alami, topografi, drainase, iklim, dan vegetasi. Jenis tanah akan memengaruhi jenis penggunaan lahan yang cocok untuk suatu tanaman dan dapat menjadi salah satu parameter yang dapat menentukan arahan fungsi pemanfaatan lahan. Jenis tanah digunakan sebagai salah satu parameter dalam menentukan arahan fungsi kawasan berdasarkan resistensi tanah terhadap erosi oleh aliran air. Jika pada suatu daerah terdapat jenis tanah yang sangat peka terhadap erosi, maka daerah pemanfaatan lahan di daerah tersebut tidak dibenarkan sebagai kawasan budidaya.

\section{c. Curah hujan}

Intensitas hujan adalah jumlah curah hujan dibagi dengan selang waktu terjadinya hujan. Curah hujan merupakan jumlah air yang jatuh di permukaan tanah datar selama periode tertentu yang diukur dengan satuan tinggi $(\mathrm{mm})$ di atas permukaan horizontal bila tidak terjadi evaporasi, runoff, dan infiltrasi. Curah hujan dibatasi sebagai tinggi air hujan (dalam $\mathrm{mm}$ ) yang diterima di permukaan sebelum mengalami aliran permukaan, evaporasi, dan peresapan/perembesan ke dalam tanah. Jumlah hari hujan umumnya dibatasi dengan jumlah hari dengan curah hujan 0,5 $\mathrm{mm}$ atau lebih. Jumlah hari hujan dapat dinyatakan per minggu, dekade, bulan, tahun atau satu periode tanam (tahap pertumbuhan tanaman).

\subsection{Daerah Penyangga}

Menurut Nugraha, dkk (2006) menyatakan bahwa kawasan penyangga adalah kawasan yang ditetapkan untuk menopang keberadaan kawasan lindung sehingga fungsi lindungnya tetap terjaga dan merupakan batas antara kawasan lindung dan kawasan budidaya. Peraturan Pemerintah Republik Indonesia Nomor 28 Tahun 2011 Tentang Pengelolaan Kawasan Suaka Alam dan Kawasan Pelestarian Alam menjelaskan bahwa daerah penyangga adalah wilayah yang berbatasan dengan wilayah dan yang bertujuan untuk menjaga keutuhan kawasan suaka alam (KSA) dan kawasan pelestarian alam (KPA), dijelaskan dalam pasal 44 ayat 2 bahwa daerah penyangga dapat berupa kawasan hutan lindung hutan produksi serta hutan hak, tanah negara bebas atau tanah yang dibebani hak. Penggunaan lahan yang diperbolehkan di daerah penyangga adalah hutan tanaman rakyat atau kebun dengan sistem wanatani (agroforestry) dengan pengolahan lahan yang sangat minim (Nugraha, 2006). Berdasarkan kriteria dari Balai Rehabilitas Lahan dan Konservasi Tanah menyatakan bahwa suatu satuan lahan ditetapkan sebagai kawasan fungsi penyangga apabila besarnya nilai skor lahannya sebesar 125-174 dan atau memenuhi kriteria umum sebagai berikut :

a. Keadaan fisik satuan lahan memungkinkan untuk dilakukan budidaya secara ekonomis.

b. Lokasinya secara ekonomis mudah dikembangkan sebagai kawasan penyangga.

c. Tidak merugikan dilihat dari segi ekologi/ lingkungan hidup bila dikembangkan sebagai kawasan penyangga. 


\section{d. Hasil dan Pembahasan}

Dalam penelitian ini, dibatasin dengan wilayah studi yaitu Kelurahan Bukit Merdeka, Sei Merdeka, Sei Seluang, Margomulyo, Argosari, Ambarawang Laut, Karya Jaya, Wonotirto dan Tanjung Harapan di Kecamatan Samboja. Berikut ini peta lokasi studi.

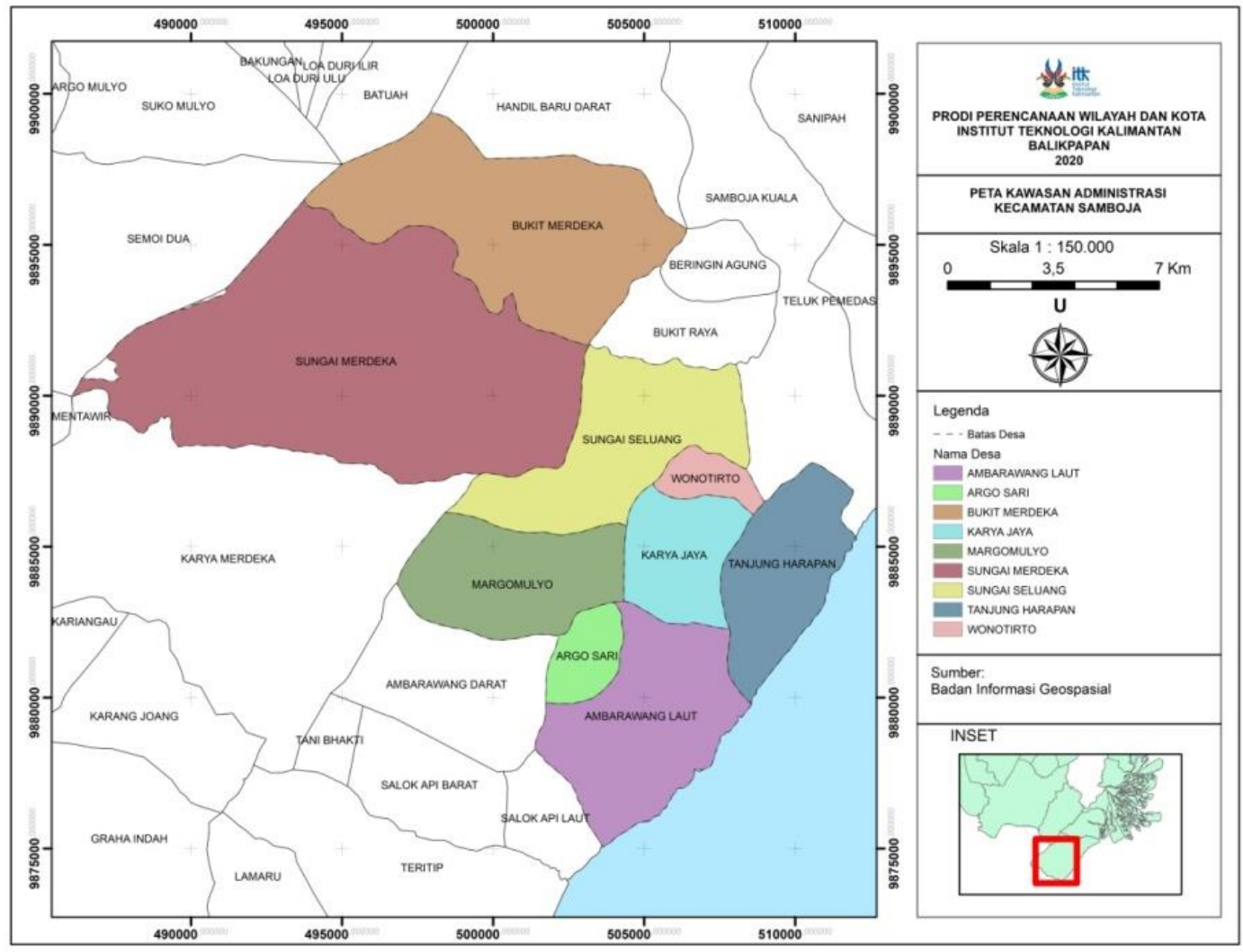

Gambar 1. Peta Lokasi Studi (Analisis Penulis, 2020)

Berdasarkan peta pada gambar 1, dilakukan analisis pada kesembilan kelurahan. Analisis yang digunakan untuk menentukan fungsi kawasan penyangga yaitu ketentuan dari Peraturan Menteri Pekerjaan Umum Nomor 41 Tahun 2007 dengan menggunakan parameter kemiringan lereng, jenis tanah dan intensitas hujan. Berikut dibawah ini gambar 2 peta kemiringan lahan, jenis tanah dan intensitas hujan di kesembilan kelurahan. 


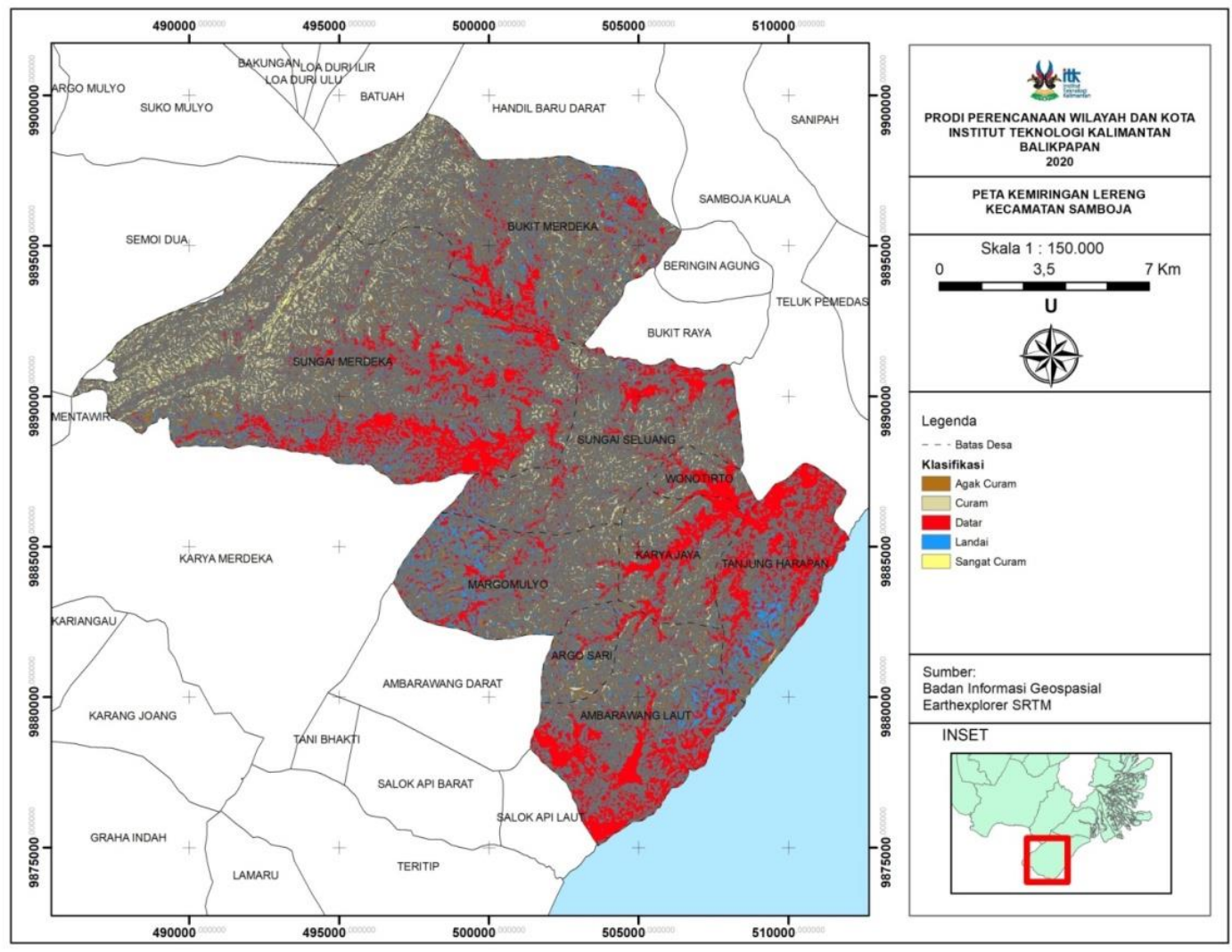

Gambar 2. Peta Kemiringan Lereng (Badan Informasi Geospasial, 2020)

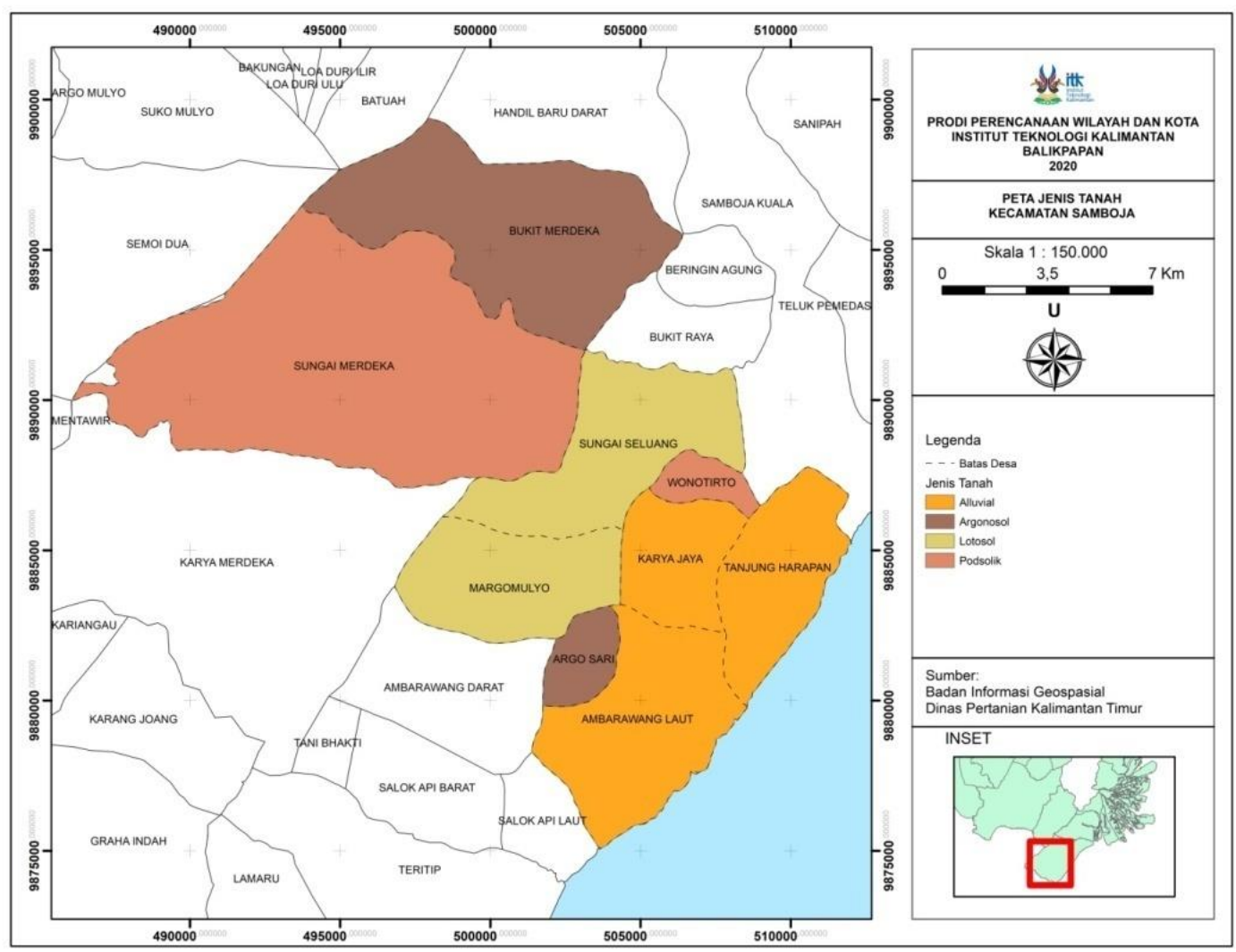

Gambar 3. Peta Jenis Tanah (Badan Informasi Geospasial, 2020) 


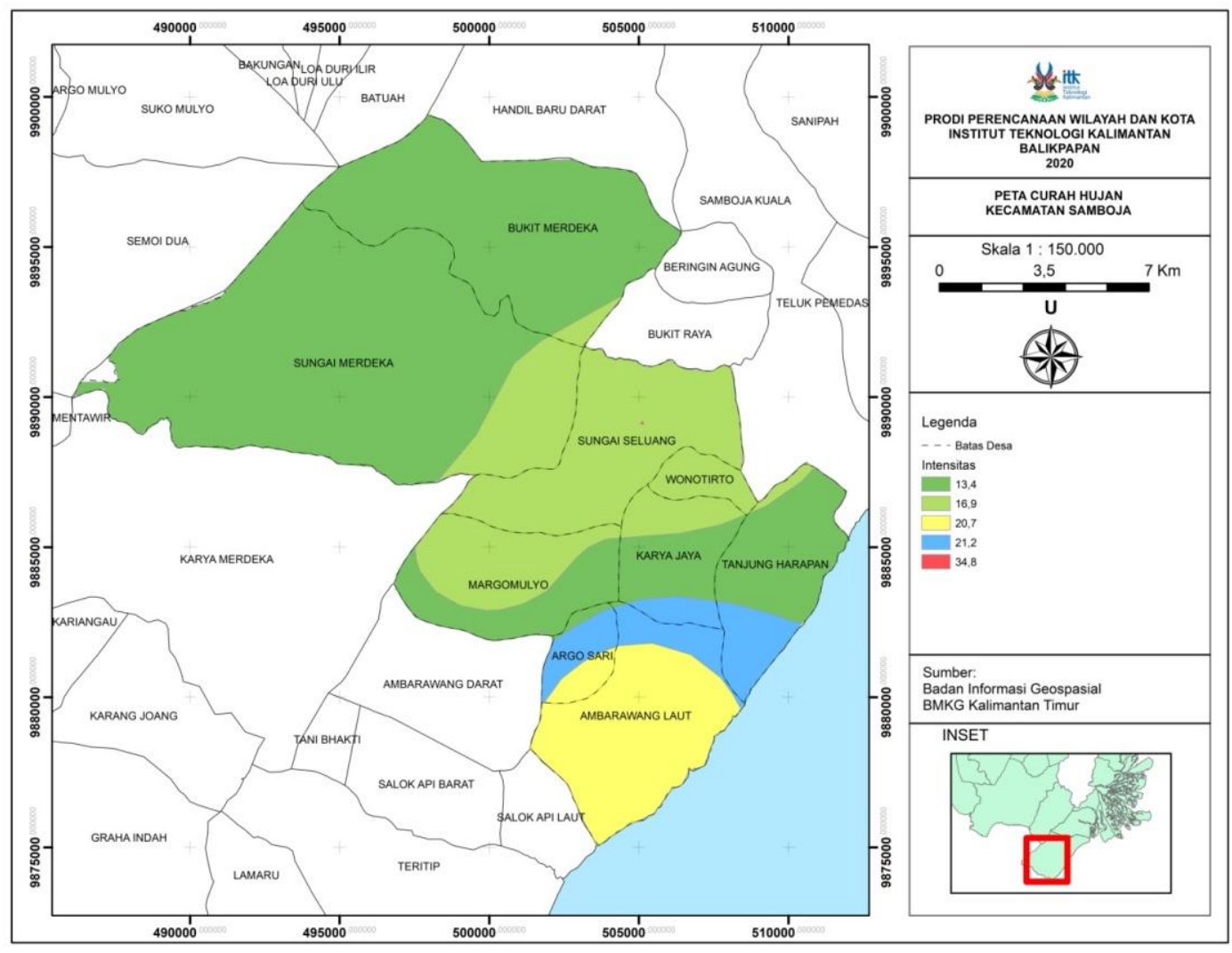

Gambar 4. Peta Curah Hujan (Badan Informasi Geospasial, 2020)

Berdasarkan kondisi eksisting kemiringan lereng, jenis tanah dan intensitas hujan dilakukan perhitungan skoring berdasarkan ketentuan dari Peraturan Menteri Pekerjaan Umum Nomor 41 Tahun 2007 menggunakan metode skoring dan overlay peta dengan alat analisis arcgis diperoleh hasil 3 (tiga) fungsi kawasan yaitu kawasan lindung, penyangga dan budidaya tanaman tahunan. Berdasarkan analisis penentuan fungsi kawasan yang telah dilakukan diketahui bahwa dari sembilan kelurahan didominasi memiliki fungsi sebagai kawasan lindung, selanjutnya kawasan budidaya tanaman tahunan dan yang terakhir kawasan penyangga. Berikut persentase luas wilayah yang memiliki fungsi sebagai kawasan lindung, penyangga dan budidaya tanaman tahunan.

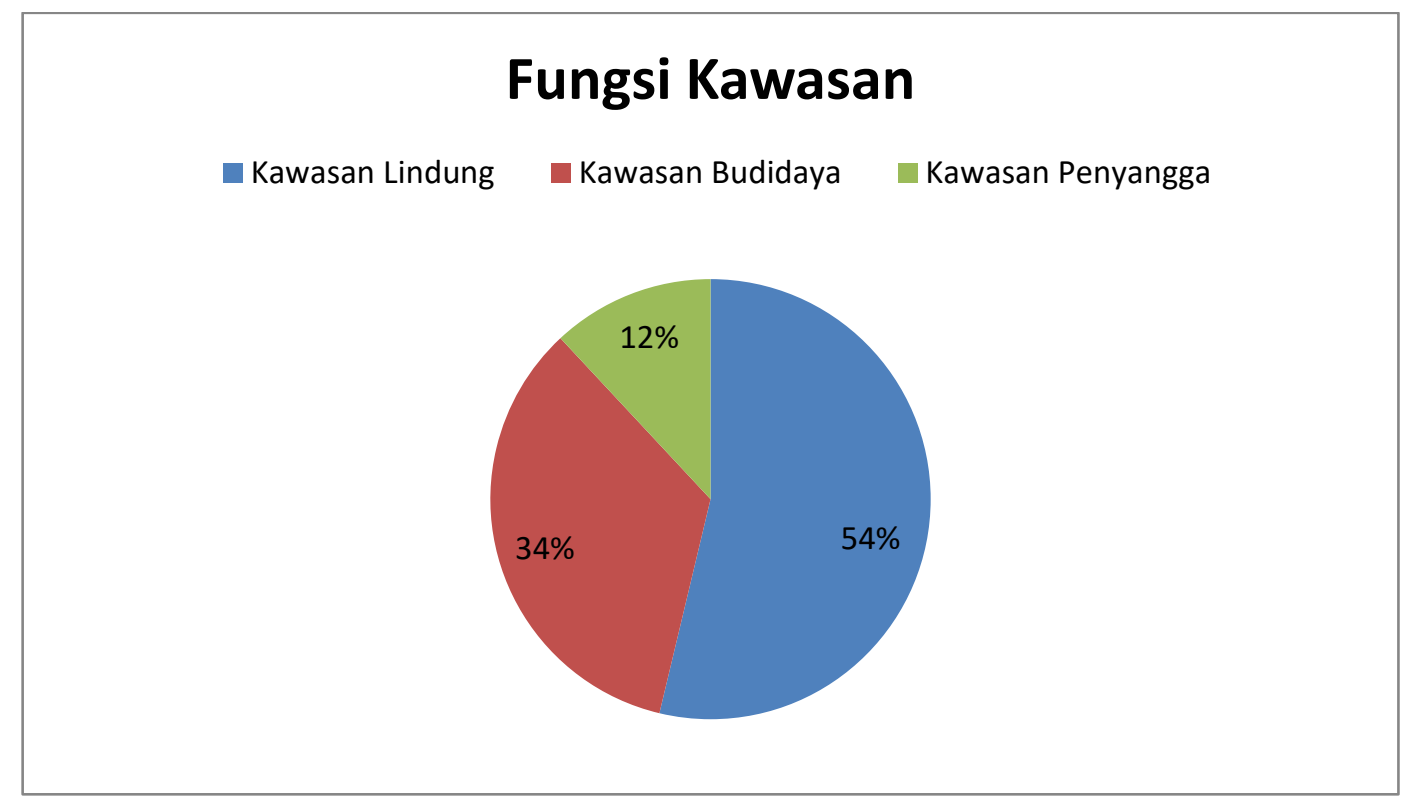

Gambar 5. Diagram Hasil Perhitungan Skoring Penentuan Fungsi Kawasan (Analisis Penulis, 2020) 
Berdasarkan diagram diatas dapat dilihat bahwa di 9 (sembilan) kelurahan terbagi menjadi 3 (tiga) fungsi kawasan dengan hasil kawasan lindung memiliki persentase 54\%, budidaya memiliki persentase $34 \%$, dan penyangga memiliki persentase $12 \%$. Hal ini menandakan bahwa terdapat $12 \%$ dari total luas lahan di sembilan kelurahan yang dapat dikategori sebagai daerah atau kawasan penyangga untuk kawasan Taman Hutan Raya (Tahura) Bukit Soeharto. Berikut pemetaan fungsi kawasan berdasarkan hasil dari perhitungan skoring berdasarkan ketentuan dari Peraturan Menteri Pekerjaan Umum Nomor 41 Tahun 2007.

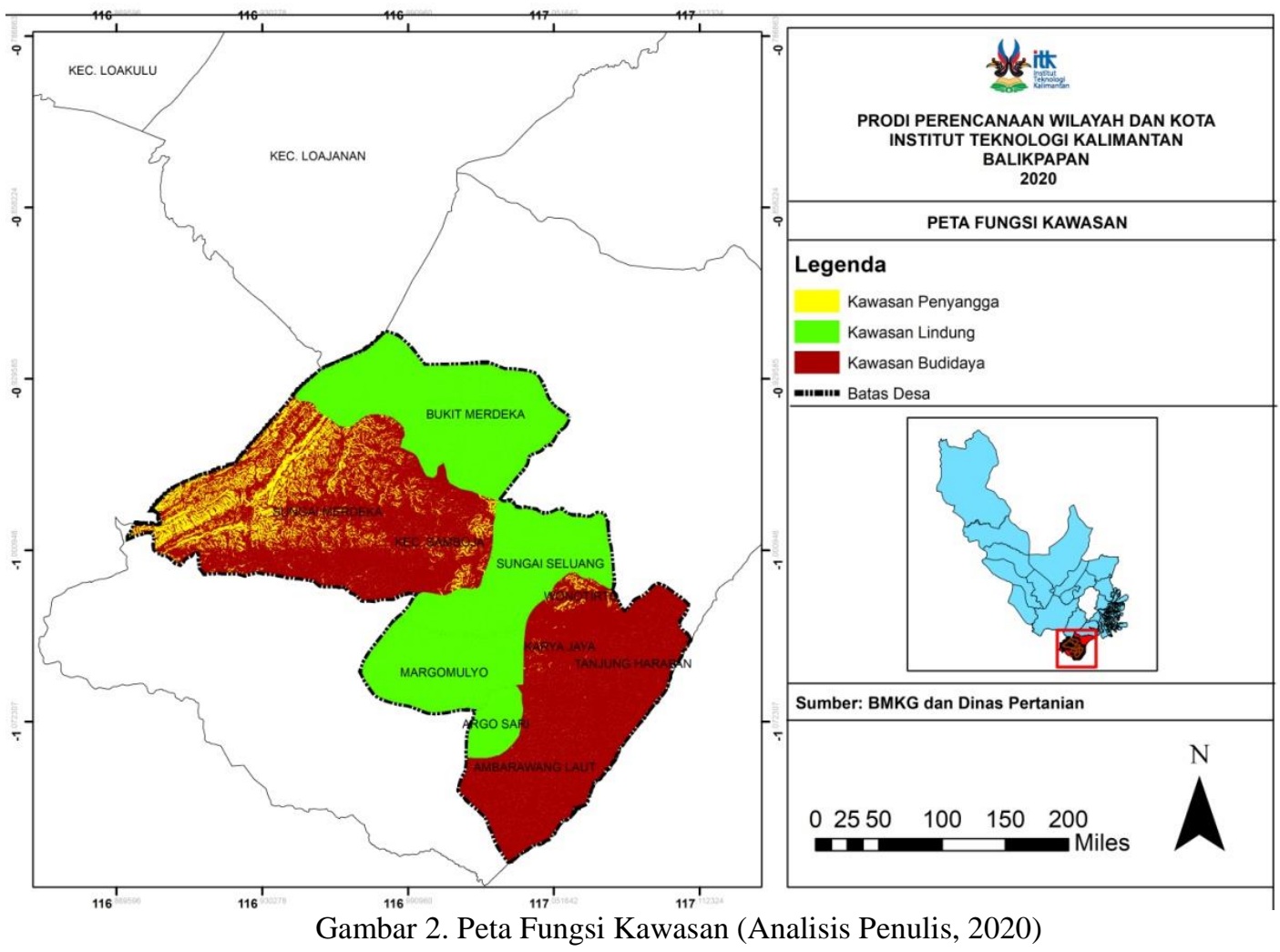

Berdasarkan ruang lingkup penelitian diketahui terdapat sembilan kelurahan yang berpotensi menjadi kawasan atau daerah penyangga karena memiliki kriteria yaitu wilayah administrasi keluarahan berbatasan dengan kawasan Taman Hutan Raya Bukit Soeharto tetapi setelah dilakukan perhitungan skoring dengan menggunakan parameter kemiringan lahan, jenis tanah dan curah hujan diketahui bahwa fungsi kawasan dari 9 kelurahan bukan hanya sebagai daerah penyanga tetapi terdapat 2 (dua) fungsi kawasan. Terdapat 3 (tiga) keluarahan yang memiliki fungsi kawasan sebagai daerah penyangga sedangkan 6 (enam) keluarahan memiliki fungsi sebagai kawasan lindung dan budidaya tanaman tahunan. Berdasarkan gambar 2 dapat dilihat bahwa kelurahan yang memiliki fungsi sebagai kawasan lindung adalah Kelurahan Bukit Merdeka, Sungai Seluang, Margomulyo, dan Argosari dengan total luas wilayah seluas 10.3 Ha, sedangkan kelurahan yang memiliki fungsi sebagai kawasan budidaya tanaman tahunan adalah Kelurahan Ambarawang Laut, Tanjung Harapan dan sebagaian di wilayah Kelurahan Sungai Merdeka, Wonotirto, dan Karya Jaya dengan total luas wilayah sebesar 14.1 Ha, dan kelurahan yang memiliki fungsi sebagai kawasan penyangga adalah sebagaian wilayah di Kelurahan Sungai Merdeka, Wonotirto, dan Karya Jaya dengan total luas wilayah seluas 2.2 Ha.

\section{e. Kesimpulan}

Berdasarkan analisis perhitungan skoring dan overlay peta pada lokasi penelitian diperoleh daerah yang berfungsi sebagai kawasan penyangga adalah sebagaian wilayah di Kelurahan Sungai Merdeka, Wonotirto, dan Karya Jaya . Selain itu terdapat daerah yang berfungsi sebagai kawasan lindung yaitu Kelurahan Bukit Merdeka, Sungai Seluang, Margomulyo, dan Argosari dan daerah yang berfungsi sebagai kawasan budidaya tanaman tahunan adalah Kelurahan Ambarawang Laut, Tanjung Harapan dan sebagaian di wilayah Kelurahan Sungai Merdeka, Wonotirto, dan Karya Jaya 


\section{Referensi}

Keputusan Menteri Kehutanan 1231 Tahun 2017 tentang Perubahan Atas Keputusan Menteri Kehutanan Nomor SK.577 /Menhut-11/2009 Tentang Penetapan Taman Hutan Raya Bukit Soeharto.

Listumbinang Halengkara. (2012). Panduan Praktikum SIG. Bandar Lampung Penerbit Universitas Lampung.

Nugraha, S., Sudarwanto, S., Sutirto, T.W, dan Sulastoro. (2006). Potensi dan Tingkat Kerusakan Sumberdaya Lahan di Daerah Aliran Sungai Samin Kabupaten Karanganyar dan Sukoharjo. Surakarta Penerbit Universitas Negeri Surakarta

Suryadi., Aipasa, Ruchaem, dan Matius. (2017). Studi Tata Guna Kawasan Taman Hutan Raya Bukit Soeharto. Samarinda Penerbit Universitas Mulawarman

Peraturan Pemerintah Nomor 68 Tahun 1998 tentang Kawasan Suaka Alam dan Kawasan Pelestarian Alam

Peraturan Menteri Perkerjaan Umum Nomor 41 Tahun 2007 tentang Pedoman Kriteria Teknis Kawasan Budidaya.

Peraturan Pemerintah Republik Indonesia Nomor 26 Tahun 2008 Tentang Rencana Tata Ruang Wilayah Nasional.

Peraturan Menteri Negara Lingkungan Hidup Nomor 17 Tahun 2009 tentang Pedoman penentuan daya dukung lingkungan hidup dan penataan ruang wilayah.

Peraturan Pemerintah Republik Indonesia Nomor 28 Tahun 2011 Tentang Pengelolaan Kawasan Suaka Alam dan Kawasan Pelestarian Alam. 